\title{
CONSEQUENCES OF GLOBAL CLIMATE CHANGE FOR GEOGRAPHIC DISTRIBUTIONS OF CERRADO TREE SPECIES
}

\author{
Marinez Ferreira de Siqueira ${ }^{1} \&$ Andrew Townsend Peterson ${ }^{2}$
}

Biota Neotropica v3 (n2) - http://www.biotaneotropica.org.br/v3n2/pt/abstract?article+BN00803022003

Date Received 01/27/2003

Revised 04/15/2003

Accepted 07/21/2003

\begin{abstract}
${ }^{1}$ Centro de Referência em Informação Ambiental - CRIA. Av. Romeu Tórtima 388. Barão Geraldo. CEP: 13083-885
.Campinas, SP, Brasil. marinez@ cria.org.br (autor para correspondência da revista)

${ }^{2}$ Andrew Townsend Peterson. Natural History Museum and Biodiversity Research Center. University of Kansas. Lawrence, Kansas 66045 USA. town@ku.edu
\end{abstract}

\begin{abstract}
The present study applies a series of new techniques to understand the conservation of Cerrado tree species in the face of climate change. We applied techniques from the emerging field of ecological niche modeling to develop a first-pass assessment of likely effects of climate change on tree species' distributions in the Cerrado biome by relating known occurrence points to electronic maps summarizing ecological dimensions. Distributional data represent 15,657 records for 162 tree species occurring in Cerrado. By focusing on the trees of one important and highly endemic biome, rather than the biota of a political unit, we were able to focus on developing biome-wide projections. An important limitation of this study is that only those species with more than 30 unique occurrence records were used-hence, the study is limited to those species of relatively broad geographic distribution, and does not take into account those species with narrower geographic distributions. Global climate change scenarios considered were drawn from the general circulation models of HadCM2; we assessed both a conservative and a less conservative scenario of how climates could change over the next 50 year using the (Hadley HHGSDX50 and HHGGAX50 scenarios, respectively): HHGSDX50 assumes 0.5\%/yr CO2 increase, whereas HHGGAX50 assumes a 1\%/yr CO2 increase. Results of predictions of present and future distributions varied widely among species. Present distributional models predicted areas of 655,211-2,287,482 out of the 2,496,230 $\mathrm{km}^{2}$ core area of Cerrado in Brazil. All models used to represent species' present geographic ranges were highly statistically significant based on independent test data sets of point localities. Most species were projected to decline seriously in potential distributional area, with both scenarios anticipating losses of $>50 \%$ of potential distributional area for essentially all species. Indeed, out of 162 species examined, between the two climate change scenarios, 18 (HHGSDX50 scenario) - 56 (HHGGAX50 scenario) were predicted to end up without habitable areas in the Cerrado region, and 91 (HHGSDX50 scenario) - 123 (HHGGAX50 scenario) species were predicted to decline by more than $90 \%$ in potential distributional area in the Cerrado region. Bearing in mind the limitations of the method, and considering its explicit assumptions, these results nevertheless should be cause for ample concern regarding Cerrado biodiversity. Since only $2.25 \%$ of the Cerrado biome is presently protected, this future scenario presents a pessimistic forecast, which would likely include widespread species loss from the biome, as well as dramatic shifts to the south and east, further complicating conservation planning efforts.
\end{abstract}

Key words: ecological niche modeling; Cerrado tree species; climate change;

http://www.biotaneotropica.org.br 


\section{Resumo}

Este estudo aplicou técnicas oriundas da emergente técnica de modelagem de nicho ecológico para desenvolver um primeiro passo no entendimento dos efeitos de mudança climática na distribuição de espécies arbóreas do bioma Cerrado, através do cruzamento de informação entre os pontos de ocorrência com coberturas ambientais resumindo as dimensões ecológicas para as espécies analisadas. Os dados de distribuição foram compostos por 15.657 registros para 162 espécies arbóreas registradas para o Cerrado. Uma importante limitação deste estudo é que, devido ao processo de modelagem empregado, o conjunto de dados utilizado apenas considerou as espécies registradas para 30 ou mais localidades diferentes, ou seja, este estudo é limitado para aquelas espécies com distribuição geográfica mais ampla, não levando em conta as espécies de distribuição mais restrita ou de ocorrências únicas. Os modelos de circulação usados foram provenientes do HadCM2, incluindo vários cenários diferentes. Foi utilizado um cenário mais conservativo e outro menos conservativo em relação ao modo como o clima poderia se alterar nos próximos 50 anos usando cenários Hadley HHGSDX50 e HHGGAX50 respectivamente. O cenário HHGSDX50 baseia-se em um aumento de $0,5 \%$ /ano de CO2 e o cenário HHGGAX50 baseiase em um aumento de $1 \%$ /ano de $\mathrm{CO} 2$ na atmosfera. $\mathrm{O}$ resultado desta modelagem mostra uma redução de área de Cerrado de aproximadamente $25 \%$ (utilizando-se o cenário mais conservativo) e de $90 \%$ (utilizando-se o cenário menos conservativo) da área original utilizada $(2.496 .230 \mathrm{Km} 2)$. Todos os modelos utilizados na distribuição presente das espécies foram altamente significativos, baseados em um conjunto independente de dados de localidades para teste. Muitas espécies tiveram projeções de declínios em suas distribuições geográficas, e, para ambos cenários utilizados, foram previstas reduções maiores que $50 \%$ para todas as espécies analisadas. Os casos mais graves foram observados para 18 espécies (para o cenário HHGGAX50) e 56 (cenário HHGGAX50) que ficaram sem projeção futura de área habitável, e 91(HHGGAX50) e 123 (HHGSDX50) tiveram sua distribuição geográfica reduzida em mais de $90 \%$ da área original dessas espécies no bioma Cerrado. Apesar das limitações do método, estes resultados não deixam de ser preocupantes, principalmente pelo fato de hoje o bioma Cerrado contar apenas com cerca de $2,25 \%$ de sua área protegida por unidades de conservação, pois além de mostrar uma perda de área habitável para muitas espécies, também mostra um grande deslocamento de áreas habitáveis em direção ao sul e leste do país.

Palavras-chave: modelagem de nicho ecológico, espécies arbóreas de Cerrado; mudanças climáticas

\section{Introduction}

Cerrado, as the Brazilian savanna vegetation is called, covers about $2 \times 10^{6} \mathrm{~km}^{2}$ of Central Brazil, representing about $23 \%$ of the land surface of the country (roughly about the size of Western Europe) (Ratter et al., 1997). In terms of area, it is exceeded only by one vegetation formation in Brazil, the Amazon forest, which covers about $3.5 \times 10^{6} \mathrm{~km}^{2}$. Cerrado vegetation is quite variable in physiognomy, ranging from tall savanna woodland with an almost-closed canopy, to much sparser shrubby forms and even treeless grassland (Eiten, 1992).

Over the last $30 \mathrm{yr}$ or so, the Cerrado region has been transformed by rapid expansion of intensive agriculture; according to Myers et al. (2000), only $20 \%$ of the original area remains the primary vegetation. This situation is of great concern because this biome is rich in endemic species; indeed, for plants, endemism reaches $44 \%$ of the total of 10,000 species (Myers et al. 2000). This high level of endemism was an important reason in the inclusion of Cerrado in the list of world-wide hotspots for biodiversity (Mittermeier 1999). On top of these concerns, climate change effects across Brazil are projected to be significant-taking the average of two low-to-middle-strength climate change scenarios from the Hadley Center (HHGGAX50 and HHGSDX50), temperature is projected to increase by as much as $23 \%$ and precipitation to decrease by as much as $24 \%$ across the country-these rather alarming figures beg some investigation of how changing climates are likely to affect Brazil's biodiversity.

The present study applies a series of new techniques to the challenge of building a better understanding of the present and potential future geographic distributions of Cerrado vegetation, and possible implications for conservation in the face of climate change. Specifically, beyond the present challenge of conserving Cerrado vegetation in the face of increasing agricultural activities, climate change presents a series of new-and very worrisome-challenges. Techniques from the emerging field of ecological niche modeling are applied to permit development of a first-pass assessment of likely effects of climate change on tree species' distributions in the Cerrado biome.

\section{Methods}

The general approach to modeling climate change effects on biodiversity is developed in detail elsewhere (Peterson et al. 2001, Peterson et al. 2002b), as are the details of the algorithm used for modeling species' ecological niches (Stockwell \& Noble 1992, Stockwell 1999, Stockwell \& Peters 1999). Previous tests of the predictive ability of this modeling technique for diverse phenomena in various 
regions have been published elsewhere (Peterson \& Cohoon 1999, Peterson et al. 1999, Peterson 2001, Anderson et al. 2002a, b, Feria \& Peterson 2002, Peterson et al. 2002a, Peterson et al. 2002c, Peterson et al. 2002d, Stockwell \& Peterson 2002a, b, Anderson et al. 2003, Peterson et al. in press-a, Peterson et al. in press-b). Tests of the application of these techniques to woody plants in South America, including 6 of the species treated herein, were highly statistically significantly better than random models. (Koch et al. Submitted).

Data on distributions and ecological dimensions.Distributional data representing 15,657 records (i.e., unique species x latitude-longitude combinations) for 162 tree species occurring in Cerrado (sensu lato) were assembled from the Projeto de Cooperação Técnica Conservação e Manejo da Biodiversidade do Bioma Cerrado - EMBRAPA Cerrados - UnB - Ibama/DFID e RBGE/Reino Unido. The distributional information was originally obtained via the method of wide patrolling (Koch et al. Submitted), which involves coordinated sweeps, recording observed species presences, and with collections made when species are not recognized, or when identification is doubtful. Species encountered were recorded in $15 \mathrm{~min}$ intervals to permit development of species accumulation curves. In all, 383 localities in Cerrado were sampled, and a total of 966 species identified.

An important limitation of this study is that only those species for which $\geq 30$ unique occurrence records were available-hence, the study considers only those species of relatively broad geographic distribution, and does not take into account species with narrower geographic distributions. Environmental data included 9 electronic map layers summarizing slope, aspect, and upward curvature ("topoind") (from the U.S. Geological Survey's (http:// edcdaac.usgs.gov/gtopo30/hydro/) Hydro-1K data set), and aspects of climate including diurnal temperature range; mean annual precipitation; maximum, minimum, and mean annual temperatures; and vapor pressure (annual means 1960-1990; from the Intergovernmental Panel on Climate Change (http:/ /www.ipcc.ch/).

Scenarios of climate change.-The general circulation models used were HadCM2 (Koch et al. Submitted); each of these climate models includes several scenarios. We assessed both a conservative and a less conservative view of how climates could change over the next $50 \mathrm{yr}$ using the Hadley HHGSDX50 and HHGGAX50 scenarios (http:// ipcc-ddc.cru.uea.ac.uk/cru data/examine/ HadCM2 info.html). The HHGSDX50 scenario assumes $0.5 \% / \mathrm{yr} \mathrm{CO}_{2}$ increase (IS92d), and incorporates sulphate aerosol forcing, making it a relatively conservative estimate of climate change. The HHGGAX50 scenario assumes a 1\%/ yr $\mathrm{CO}_{2}$ increase (IS92a) and does not allow for the effects of sulfate aerosols, and so is less conservative. Results are based on a $30 \mathrm{yr}$ average around 2055 (2040-2069), and there- fore our models do not take into account the potential effects of increased climate variability (El Niño events, in particular) on species' distributions.

The future projected climate data are provided at a spatial resolution of $2.5 \times 3.75^{\circ}$ (Carson 1999). To improve spatial resolution, however, following recommended methodologies (http://www.ipcc.ch/), we calculated expected changes in each climate variable for each scenario and each of the relatively coarse pixels via subtraction of future from present model results. These difference maps were then applied to the more detailed $\left(0.5 \times 0.5^{\circ}\right.$ cells $)$ IPCC current climate data layers, which are developed and provided by the same organism, and which are intended to be parallel and consistent with the climate-model projections.

Ecological niche modeling and dispersal assumptions.-The ecological niche of a species can be defined as the conjunction of ecological conditions within which it is able to maintain populations without immigration (Grinnell 1917, Holt \& Gaines 1992); as such, it is defined in multidimensional ecological/environmental space (MacArthur 1972). Several approaches have been used to approximate species' ecological niches (Austin et al. 1990); of these, the most robust appears to be the Genetic Algorithm for Ruleset Prediction (GARP), which includes several inferential approaches in an iterative, artificial-intelligence-based approach (Stockwell \& Peters 1999).

All modeling in this study was carried out on a desktop implementation of GARP now available publicly for download (http://beta.lifemapper.org/desktopgarp/). Available occurrence points are divided evenly into training and test data sets. GARP is designed to work based on presence-only data; absences are included in the modeling exercise via sampling of pseudoabsence points from the set of pixels where the species has not been detected. GARP works in an iterative process of rule selection, evaluation, testing, and incorporation or rejection: first, a method is chosen from a set of possibilities (e.g., logistic regression, bioclimatic rules), and then is applied to the training data and a rule developed; rules may evolve by a number of means (e.g., truncation, point changes, crossing-over among rules) to maximize predictivity. Predictive accuracy is then evaluated based on 1250 points resampled from the test data and 1250 points sampled randomly from the study region as a whole. The change in predictive accuracy from one iteration to the next is used to evaluate whether a particular rule should be incorporated into the model, and the algorithm runs either 1000 iterations or until convergence.

Ecological niche models developed with GARP can be projected onto both current and modeled future landscapes. Projection onto the current landscape provides an estimate of present-day geographic distribution of suitable conditions. GARP models consist of an ordered series of ifthen statements that predict either presence or absence; these statements can be applied to the transformed land- 
scapes to identify areas of potential distribution for a species after the modeled sequences of environmental change.

We thus synthesized the pre- and post-change maps for each species by measuring potential distributional area under assumptions regarding dispersal ability. Unlike previous studies (Peterson et al. 2001, Peterson et al. 2002b), given the minimal dispersal abilities of tree species over the short time span in which drastic climate changes are expected, only a single dispersal assumption was examined. We assumed that species were unable to disperse and would inhabit only those portions of present distributional areas that remain habitable (i.e., the modeled actual distribution was reduced to those areas predicted to be habitable post change). Overall, these analyses assume no evolution in niche characteristics (Peterson et al. 1999), and do not take into account interactions among species such as competition, predation, etc. Given the diverse conditions present across the geographic distribution of the Cerrado, our models appear not to be extrapolating beyond the environmental conditions on which they were fitted; regardless, though, the predictivity of this approach has proven quite high (Peterson et al. 1999, Martínez-Meyer 2002).

To translate distributional patterns into target areas for conservation, we used a heuristic complementarity approach based on interpolated geographic distributions that we have developed in detail elsewhere (Egbert et al. 1998, Godown \& Peterson 2000, Peterson et al. 2000, Chen \& Peterson 2002). The approach is based on the principle of complementarity among areas (Myers 1988, Dinerstein and Wikramanayake 1993, Lomolino 1994, Csuti et al. 1997). Although complex, globally optimal approaches have been developed (Csuti et al. 1997), we use a simpler heuristic approach owing to the very large number of pixels that are prioritized in our application ( 85,000). Here, an initial step consists of summing species' distributions to identify the area of maximum species richness; species occurring in this area are identified, and eliminated from further analysis. The remaining species are summed, the area representing their peak richness identified, and the process continues until no additional areas of richness $>1$ species can be identified.

\section{Results}

Results of predictions of present and future distributions varied widely among species. Present distributional models predicted areas of $655,211-2,287,482$ out of the 2,496,230 $\mathrm{km}^{2}$ core area of Cerrado in Brazil (reflecting the fact that relatively broadly distributed species form the basis for this study). All models used to represent species' present geographic ranges were highly statistically significant based on independent test data sets of point localities (chi-square tests, df $=1, P<<0.05$ ). Example species are shown in Figure 1: many of the species examined are pre- dicted to be distributed broadly throughout the Cerrado region.

Projections of potential distributional areas for these species in 2055 (Figure 1), based on two scenarios of global climate change, indicate serious anticipated effects on Cerrado tree diversity in coming decades. The species richness peak is singular at present, with a region of maximum modeled species richness in northeastern Goiás, Brazil (Figure 2). This peak disappears, and breaks up into a broader, more scattered series of moderate-diversity peaks, under both future scenarios (Figure 2).

Most species were projected to decline seriously in potential distributional area (Figure 3), more seriously so in the HHGGAX50 scenario than in the HHGSDX50 scenario. In both cases, our models anticipate losses of $>50 \%$ of potential distributional area for essentially all species. Indeed, out of 162 species examined, 18 (HHGSDX50 scenario) - 56 (HHGGAX50 scenario) were predicted to end up without habitable areas in the Cerrado region (extinction in Cerrado), and 91 (HHGSDX50 scenario) - 123 (HHGGAX50 scenario) species were predicted to decline by $>90 \%$ in potential distributional area in the Cerrado region. An interesting question is whether current distributional area of species is at all related to severity of climate change effects on potential distributional area (i.e., is distributional area related to vulnerability to climate change effects): no significant association was found (linear regression, $\mathrm{R}^{2}=0.038, P>0.05$; Figure 4), which suggests that restricted-range species are not necessarily more vulnerable to climate change effects; still, it should be noted that this analysis does not include species with very small geographic distributions.

Current modeled species diversity among Cerrado trees had a very simple, single-peak distribution (Figure 2). In the sense of area-selection for conservation, this distribution leads to a very simple solution: a single site in northeastern Goiás, Brazil (of course, a broader suite of areas is merited as a safety net for avoidance of disasters, representation of genetic diversity within species, etc.) (Figure 5). However, the picture is quite different as species' ecological needs are projected into the future: the single peak breaks up into several that follow the southern and eastern fringe of the present distribution of Cerrado (Figure 2). Selection of areas that are maximally complementary in the two future scenarios (Figure 5) confirms this revised view of priority areas: in the HHGSDX50 scenario, the first 5 areas selected included 141 out of the 145 species $(87,38,7,6$, and 3 species, respectively) not predicted to go extinct in the Cerrado, and extended from the Paraguay border in the south, north and east to an area in western Bahia. The general geographic picture was similar in the HHGGAX50 scenario, but only 103 of the 108 remaining species $(63,32$, and 8 species) were included in the first 3 areas (subsequent to 3 areas, no species had overlapping distributional areas). 


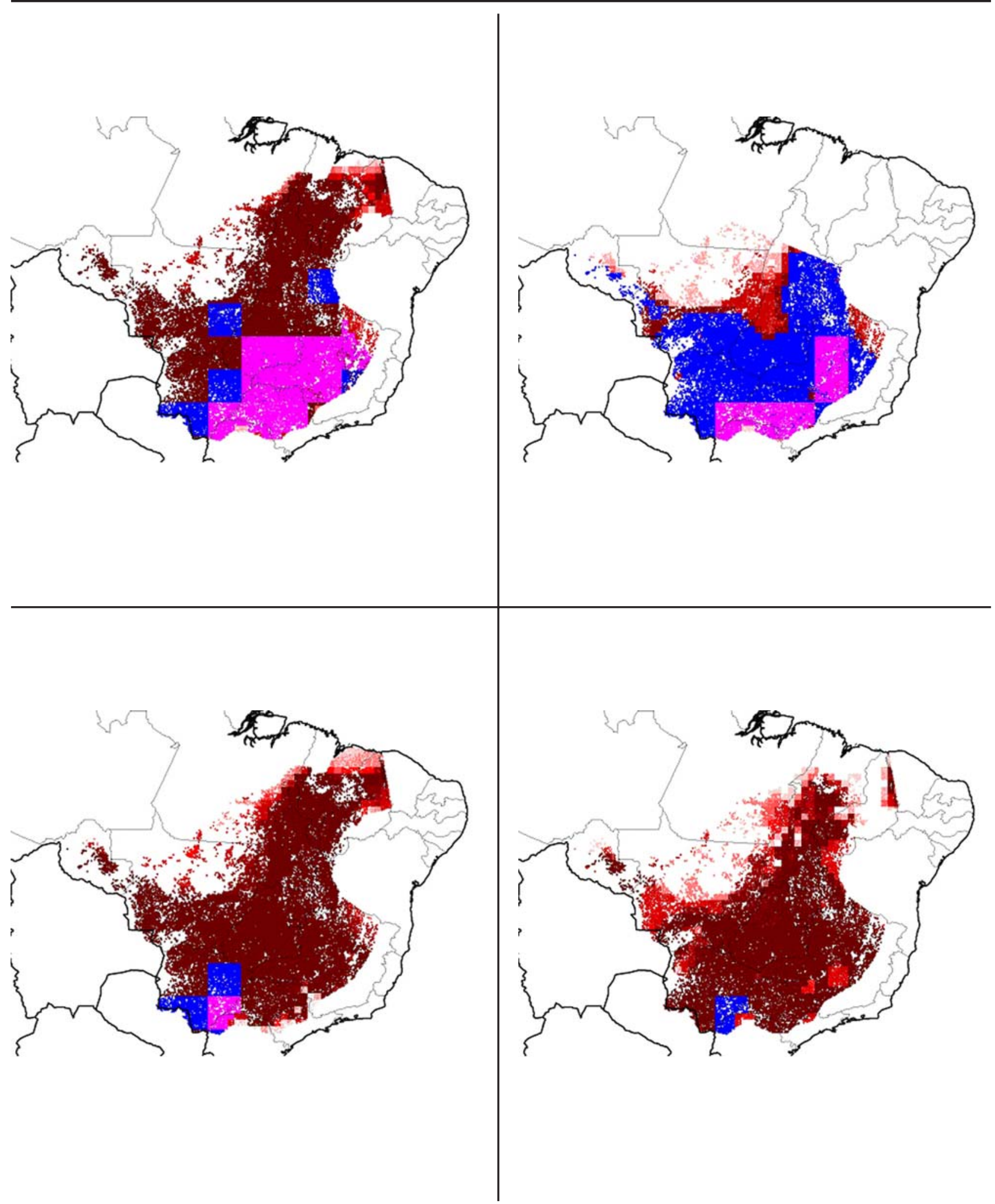

Figure 1. Examples of predictions of present (1961-1990) and future (2055) distributions of cerrado tree species. Present distributions are depicted as a surface of increasing confidence in prediction of presence in darker colors of red. That part of the distribution predicted at highest confidence levels (all best-subsets models agree) that is projected to remain habitable in 2055 (HHGSDX50 scenario) is colored blue, and that portion projected to remain habitable in 2055 (HHGGAX50 scenario) is colored pink. As these the area predicted present at highest level by the HHGSDX50 scenario is a subset of that area predicted at present, and the area predicted at highest level by the HHGGAX50 scenario is a subset of the area in the HHGSDX50 scenario, colors are overlapped in a single map. Species are as follows: upper left - Qualea grandiflora. upper right Acosmium subelegans, lower left Qualea parviflora, and lower right Rapanea guianensis. 

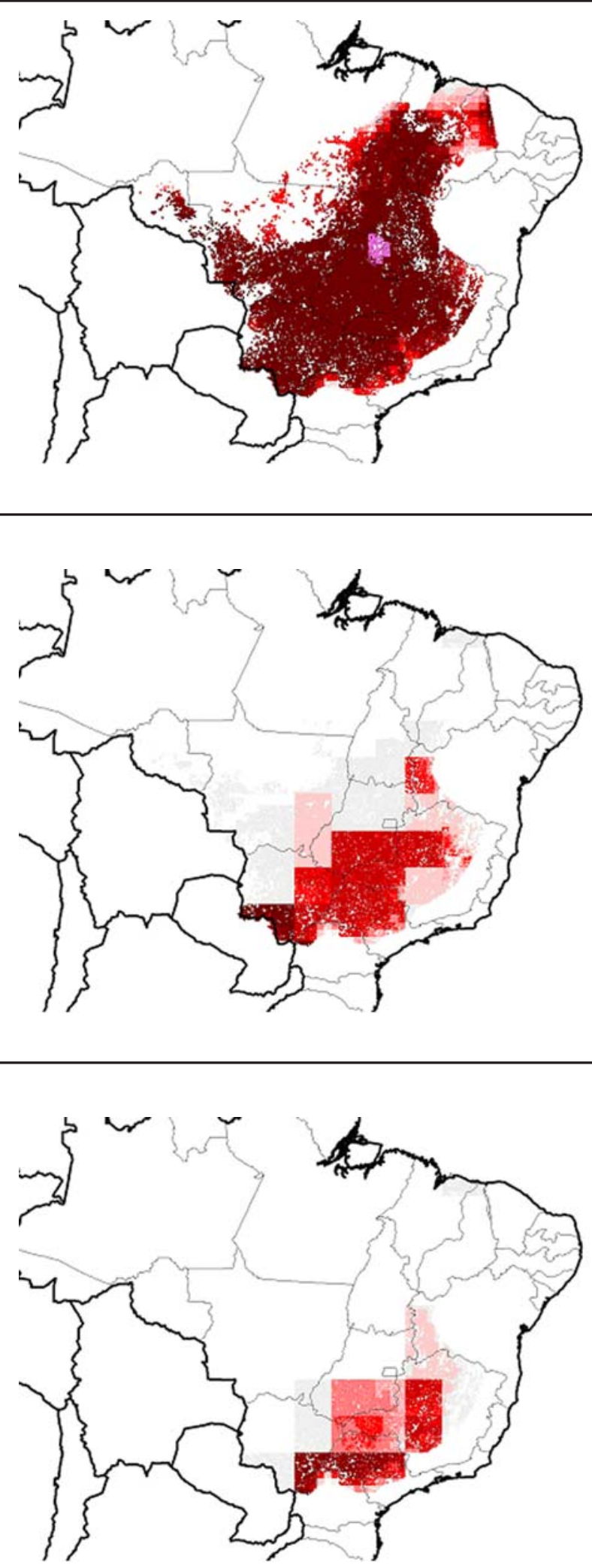

Figure 2. Patterns of predicted species richness among the 162 species of cerrado trees analyzed in the core distributional area of cerrado in central and eastern Brazil. Top, present (1961-1990); middle, HHGSDX50 (conservative) climate change scenario; and bottom, HHGGAX50 (less conservative) climate change scenario. 


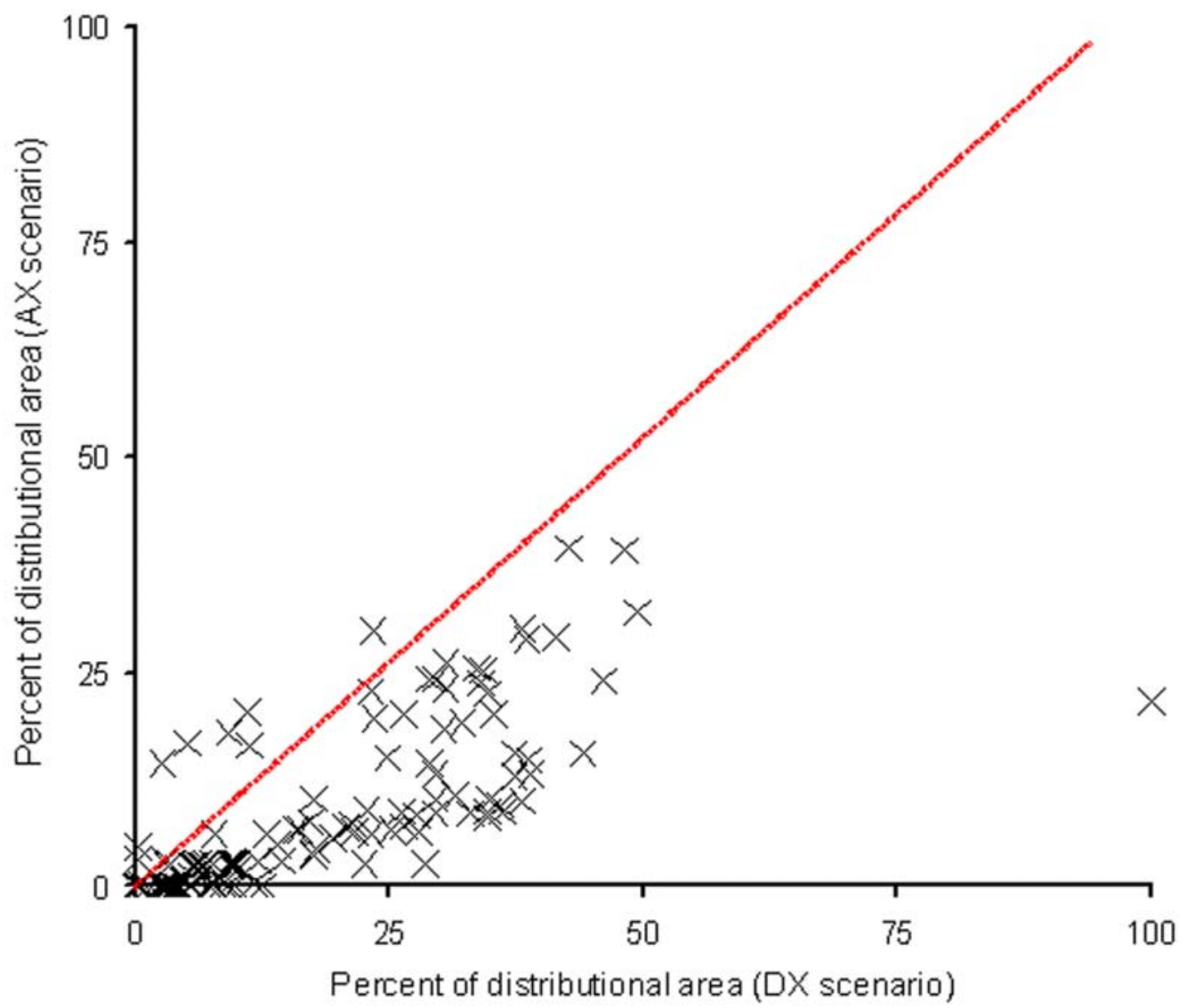

Figure 3. Relationship of severity of prediction of climate change consequences in the HHGSDX5O and HHGGAX50 scenarios. $100 \%$ represents no predicted change in potential distributional area. The dotted red line indicates equal effects between the two scenarios.

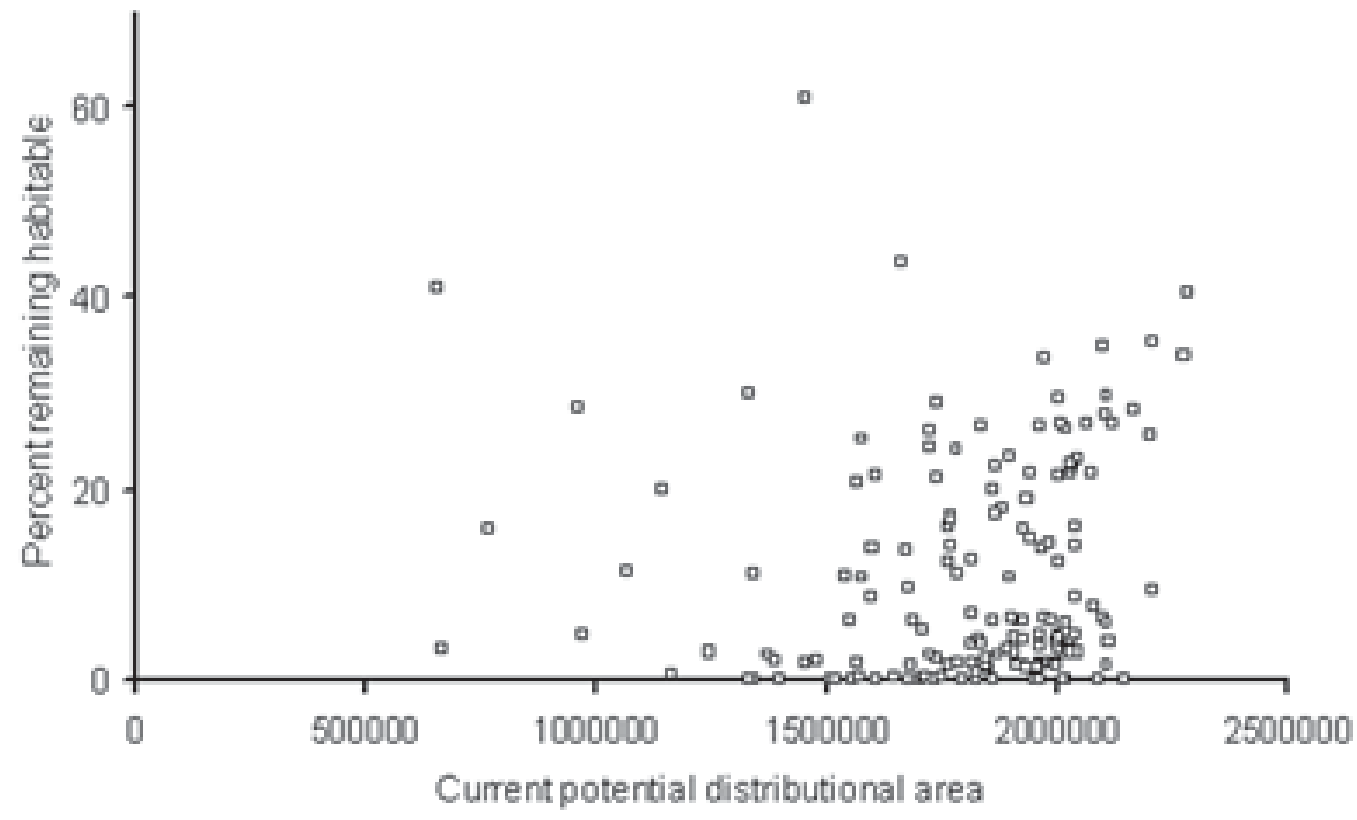

Figure 4. Modeled percent of present distributional area remaining habitable as a function of present distributional area ( $\mathrm{km}^{2}$ ), showing no consistent relationship (linear regression, $R^{2}=0.038$ ). 

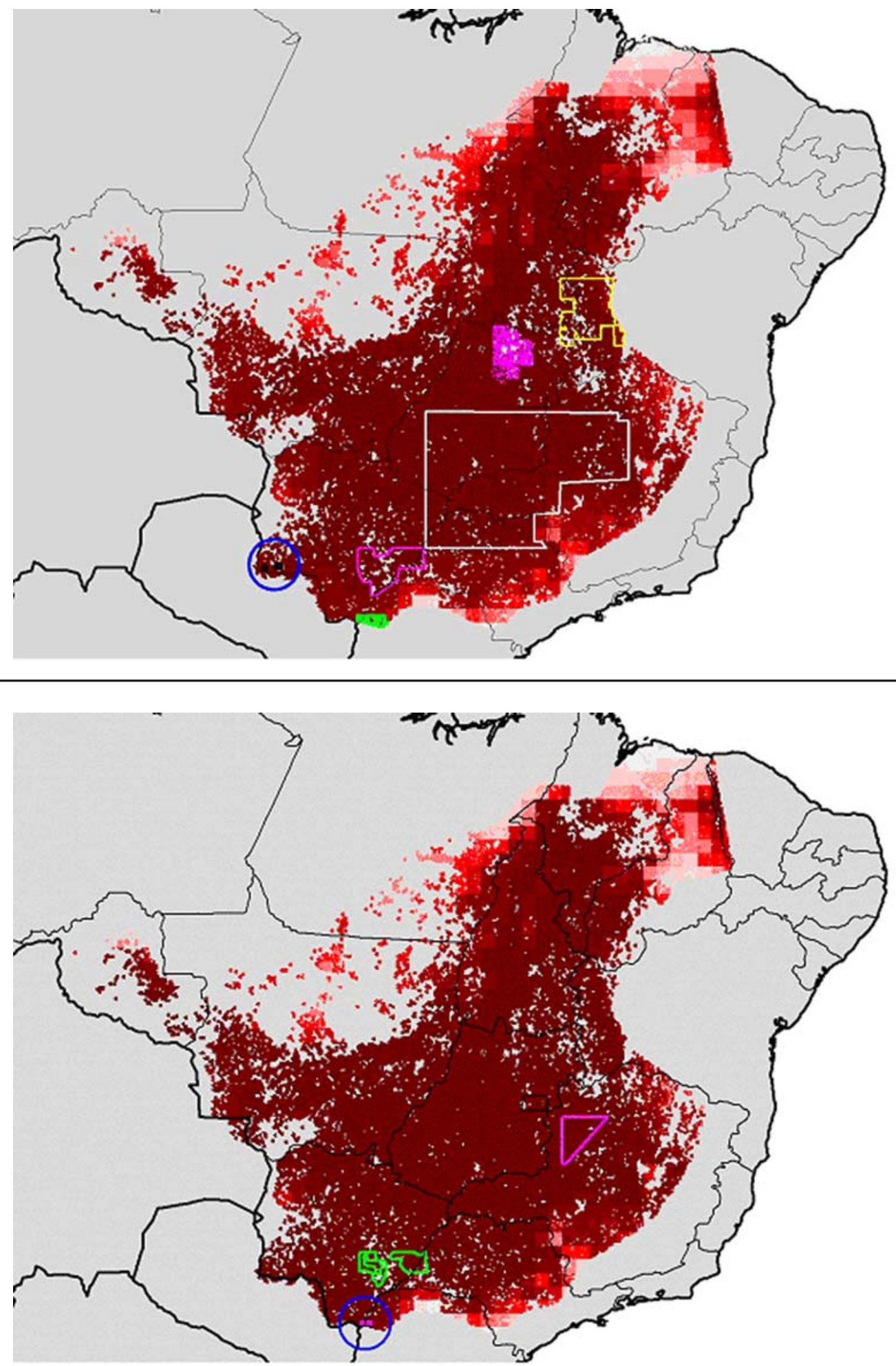

Figure 5. Prioritization of areas for conservation in the face of changing climates, based on two scenarios of global climate change: HHGSDX50 (top) and HHGGAX50 (bottom). The surface of present modeled species richness is shown as a color ramp of increasingly dark shades of red, with the area of peak modeled richness (162 species) shaded pink. Areas that represent optimal areas in a complementarity algorithm are outlined and overlaid. For DX, area 1 (blue circle indicates approximate position), 87 species; area 2 (green area at southern extreme, 38 species; area 3 (pink outline), 7 species; area 4 (yellow outline), 6 species; and area 5 (white outline), 3 species. For AX, area 1 (blue circle), 63 species; area 2 (green outline), 32 species; and area 3 (pink outline), 8 species. 


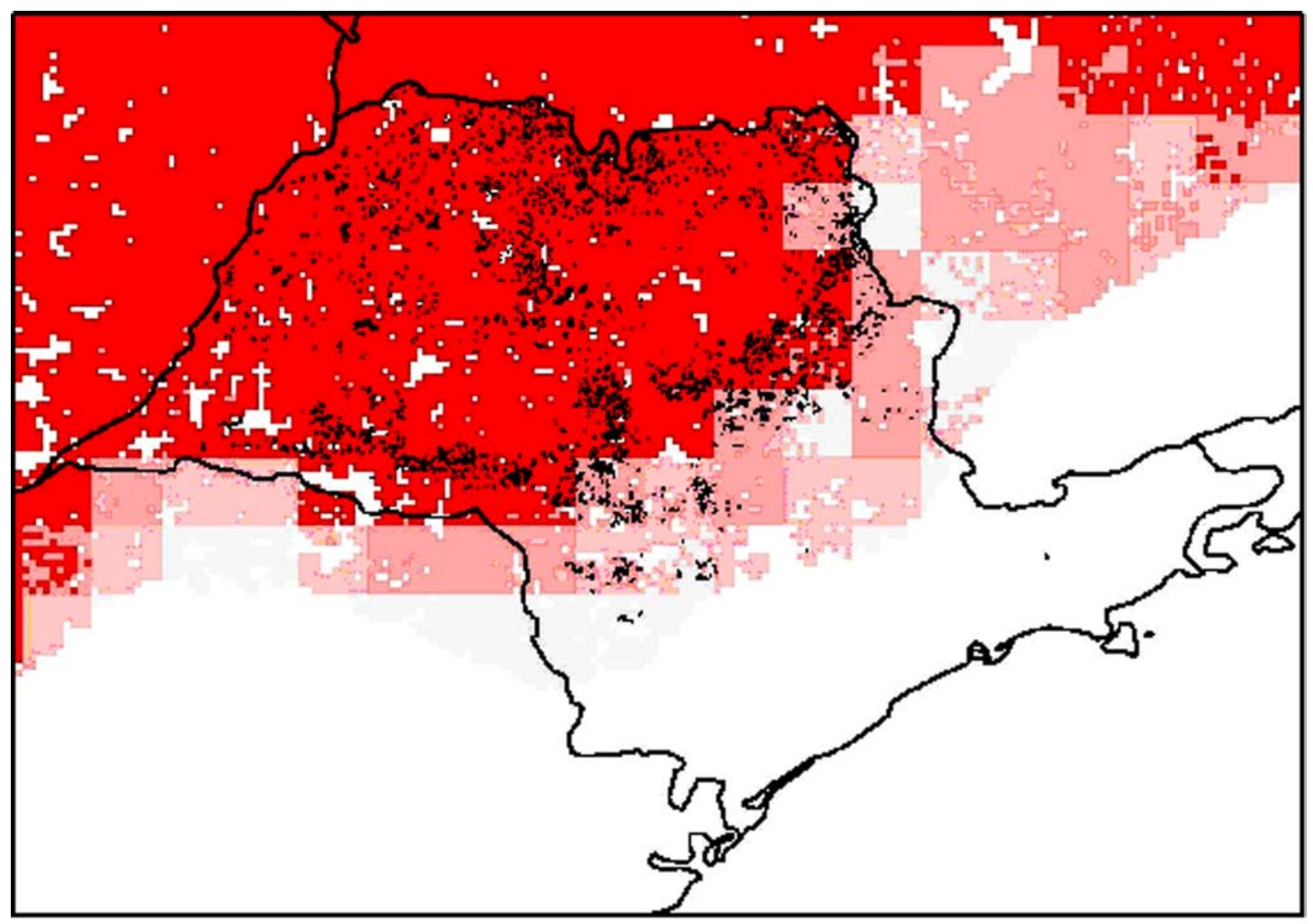

Figure 6. Illustration of the contrasts between modeled potential geographic distribution of cerrado tree species (light gray $=1-80$ species, lightest red $=81-120$ species, light red $=121-140$ species, red $>140$ species) and the actual distribution of patches of the vegetation type (data from Sistema de Informação Ambiental do Programa BIOTA- FAPESP, http://sinbiota.cria.org.br). 


\section{Discussion}

This study represents one of few broad-spectrum surveys of anticipated climate change effects on biodiversity at the species level carried out to date (Bakkenes et al. 2002, Erasmus et al. 2002, Peterson et al. 2002b). By focusing on the trees of one biome, which has extremely high endemism (44\%) among plant taxa (Myers et. al. 2000), rather than the biota of a political unit (Peterson et al. 2002b), we are able to focus on biome-wide projections, and this study has immediate implications for the broader biodiversity of the Cerrado. However, this modeling and projection exercise has limitations, which should be reviewed before the biological and conservation implications are considered.

Limitations of climate change projections for Cerrado trees.-The principal limitation in the development of climate change projections for species' geographic distributions is the availability of fine-grained future climate models. The modeled climate data used herein had a native spatial resolution of $2.5 \times 3.75^{\circ}$ (Carson 1999), which we downscaled crudely to $0.5 \times 0.5^{\circ}$ via application of change scenarios to finer-resolution present-day climate maps. Nevertheless, even the $0.5^{\circ}$ resolution is unsatisfactory for detailed consideration of species' distributions. A clear and pressing solution to this challenge is that of shifting distributional modeling efforts to be based on regional (not global) climate models (e.g., VEMAP - http://www.cgd.ucar.edu/ vemap/) that can provide better spatial resolution.

A second important limitation of this implementation of climate change projections for species' distributions is that of the availability of point-occurrence information for species outside of the Cerrado biome. That is, our models have the potential to underestimate the breadth of species' ecological niches because conspecific populations in other biomes were not generally represented in our point-occurrence data set. Although tests of this complication for 3 species for which information was available indicated excellent predictions of entire distributions of species from the Cerrado occurrence data (Siqueira unpubl. data), this problem must be borne in mind as potentially serious.

Our approach also does not take into consideration other factors that may affect ecological and geographic distributions of species, including interactions with other species (e.g., competitors, pollinators, predators, pathogens), which under certain circumstances may play important roles in shaping distributions (Davis et al. 1998). Other factors, such as dispersal ability, were treated here under restrictive assumptions (i.e., no dispersal ability). Recent information regarding natural history and basic biology (Oliveira \& Marquis 2002, Oliveira \& Gibbs 2002) of most Cerrado woody plants (Ratter et al. 1996) makes possible a more informed interpretation of the results and patterns that we foundsuch information should be taken into account in the devel- opment of conservation strategies based on our data and results.

Another important consideration is the changing picture of land use, and its interactions with climate change effects on species' distributions. Sala et al. (2000), for example, considered evolving land use patterns to have much more immediate effects on species' distributional patterns than climate change per se, and a few studies have attempted to consider both factors simultaneously (Bethke \& Nudds 1995, Benning et al. 2002). Although such factors clearly are important-evolving patterns of land use in the face of changing climates will certainly define the fine-scale limitations on distributional patterns of natural vegetation-they will, nevertheless operate within the framework of possibilities assessed in the present study.

This study was based on Cerrado tree species for which large samples $(\geq 30)$ of unique point occurrences were available. This limitation, which was based on sample sizes generally necessary for high-quality distributional predictions (Stockwell \& Peterson 2002b), necessarily limited our analyses to species with relatively broad distributions. Although explorations are underway to develop a solution to this complication (Peterson et al., unpubl. data), this problem is of particular concern in the present application, as many species $(\sim 30 \%)$ are known from single sites only.

Finally, the present study was developed in terms of before-and-after potential distributional areas only. Clearly, a decade-by-decade picture of the shifts anticipated herein would provide much-improved detail regarding changes to be expected. Moreover, the high degree of fragmentation of Cerrado and related habitats could not be taken into consideration given the temporally heterogeneous nature of the occurrence information and the lack of before-and-after views of land use patterns in the Cerrado biome. The actual fragmentation of Cerrado vegetation in Brazil is of great concern and in São Paulo State it is extreme (Figure 6), so the broad-scale analyses developed herein will eventually have to be interpreted in the view of present land-use patterns.

Comparison with Mexico.- - This study was developed using methods and data sets directly comparable to those used in a recent survey of climate change effects on sectors of biodiversity (birds, mammals, butterflies) in Mexico (Peterson et al. 2002b). Mexico is a very mountainous country, whereas the Cerrado region is much more flat. Other studies with these methodologies and data sets have noted striking contrasts in climate change effects on species' distributions depending on such topographic contrasts (Peterson 2003). Although the taxa involved are not the same, in the sense of understanding this relatively new methodology and its implications and sensibilities, the striking contrast of distributional consequences is worthy of comment. 
In the Mexican analyses, most species lost little $(<50 \%)$ of their potential distributional area, even under the relatively harsh 'no dispersal' assumption employed in the Cerrado tree analyses. This result stands in contrast to the Cerrado tree results, in which species invariably lost much more than $50 \%$ of their distributional areas. A commonality is that in both sets of analyses, species' distributional responses to climate change were not simple and predictable, emphasizing the idiosyncratic nature of species' responses to climate change (Bakkenes et al. 2002, Peterson et al. 2002b) and the inadequacy of broad-brush, biome-level projections (Chapin et al. 2000). The contrast in severity of results points strongly towards the differences in severity of climate change effects on biodiversity between mountainous regions and flatlands regions that has been pointed out elsewhere (Peterson 2003)-flatlands regions (such as the Cerrado ) are, in the end, much more vulnerable to broadscale horizontal translations of habitable areas for species.

Implications for Cerrado conservation.--Since the 1960s, Cerrado has been under intense pressure from broad agricultural expansion (Klink et al. 1993). In just $15 \mathrm{yr}$, the spatial extent of human activity in the Cerrado rose from $29 \%$ (1985) to 50\% (2000) (Nepstad et al. 1997). In spite of large areas of Cerrado remaining in central Brazil, the increasing pressure on this ecosystem is of particular concern because the biome is underrepresented among Brazilian protected areas. In fact, only $2.25 \%$ (considering conservation units of direct and indirect use) of the original area of the biome occurs in protected areas (Ministério do Meio Ambiente 1998). However, to achieve a better level of protection for Cerrado, it is necessary to take into account that it is so extense, so heterogeneous, and so rich in rare species (Ratter et. al. 2002). Hence, the area presently preserved must be expanded to include the various floristic sub-provinces within the biome. This within-biome variation is little appreciable in the present study owing to the generally broad distributions of the taxa studied.

In terms of present species richness, a "core area" of the Cerrado can easily be identified in central Brazil (Ratter et al. 2002). Although this area is generally considered to be richer in species than peripheral areas, results from the Conservação e Manejo da Biodiversidade do Bioma Cerrado project show that some peripheral Cerrado areas (drainage areas of the rivers Araguaia, Tocantins, and Xingu, and areas of the Cerrado in São Paulo State) may equal or even exceed the diversity present in core areas. Unfortunately, several of these peripheral areas are now severely perturbed-in São Paulo, only $0.95 \%$ of the original extent of Cerrado remains intact (Kronka et al. 1998), which is certainly having implications in terms of genetic variability and demographic viability of some populations.

The present study presents a further complication in such considerations. What is today the diversity peak, roughly corresponding to the core areas that have been identified previously, is not expected to continue to be a diversity peak in coming decades. Rather, if our model projections are even close to being reasonable, conservation in the Cerrado will become a considerably more complex endeavor-numerous peripheral areas will have to be considered in order to include even a moderate portion of Cerrado tree diversity.

The Workshop of Priority Areas for Conservation in the Cerrado Region (Brasil 1999) identified 87 important areas for conservation, of which more then 30 represent areas south and southeast of the present distribution pattern of the cerrado. Cavalcanti \& Joly (2002) presented several methods and respective results for identifying priorities for biodiversity conservation in the cerrado region. The authors consider that if only about $20 \%$ of the cerrado is still undisturbed, then it would be a reasonable goal to preserve at least $10 \%$ of the biome. In this context, we hope that our results serve to bolster the argument to focus attention on areas south and southeast of the present diversity peaks in the Cerrado. These areas, while highly fragmented and occupied by agriculture and urban expansion (Cavalcanti \& Joly 2002), may nevertheless be key in future conservation of the Cerrado, if the climate change projections become reality.

\section{Acknowledgments}

Many thanks to the team of researchers involved in the Projeto de Cooperação Técnica Conservação e Manejo da Biodiversidade do Bioma Cerrado - EMBRAPA Cerrados - UnB - Ibama/DFID e RBGE/Reino Unido for their generosity in making occurrence data available to us. A special thanks to Ricardo Scachetti Pereira for invaluable assistance in the technical development of these analyses. We would like to thank Dr. James Ratter, Dr. Sam Bridgewater, Dr. Giselda Durigan and Dr. Felipe Ribeiro for reading the manuscript and for contributing with valuable suggestions. Funding was provided by the U.S. National Science Foundation. ATP's work in Brazil was supported by a grant from the Fundação de Amparo à Pesquisa do Estado de São Paulo.

\section{Literature Cited}

1.ANDERSON, R. P., LAVERDE, M. \& PETERSON, A.T. 2002. Geographical distributions of spiny pocket mice in South America: Insights from predictive models. Global Ecology and Biogeography 11:131-141.

2.ANDERSON, R. P., LEW, D. \& PETERSON, A.T. 2003. Using intermodel variation in error components to select best subsets of ecological niche models. Ecological Modelling 162:211-232. 
3.AUSTIN, M. P., NICHOLLS, A. O. \& C. R. MARGULES. 1990. Measurement of the realized qualitative niche: Environmental niches of five Eucalyptus species. Ecological Monographs 60:161-177.

4.BAKKENES, M., ALKEMADE, J. R. M., IHLE, F., LEEMANSAND, R. \& LATOUR, J. B. 2002. Assessing effects of forecasted climate change on the diversity and distribution of European higher plants for 2050. Global Change Biology 8:390-407.

5.BENNING, T. L., LAPOINTE, D., ATKINSON, C. T. \& VITOUSEK, P. M. 2002. Interations of climate change with biological invasions and land use in the Hawaiian Islands: Modeling the fate of endemic birds using a geographic information system. Proceedings of the National Academy of Sciences USA 99:14246-14249.

6.BETHKE, R. W., \& NUDDS, T. D. 1995. Effects of climate change and land use on duck abundance in Canadian prairie-parklands. Ecological Applications 5:588-600.

7.BRASIL. 1999. Ações Prioritárias para Conservação da Biodiversidade do Cerrado e Pantanal. Brasília: Ministério do Meio Ambiente, FUNATURA, Conservation International, Fundação Biodiversitas, Universidade de Brasília.

8.CARSON, D. J. 1999. Climate modelling: Achievements and prospects. Quarterly Journal of the Royal Meteorological Society 125:1-27.

9.CAVALCANTI, r. b. \& Joly, C.A. 2002. Biodiversity and Conservation Priorities in the Cerrado Region. In: The Cerrados of Brazil. Ecology and Natural History of a Neotropical Savana. (Oliveira, P. E. \& R. J. Marquis, R. J. eds). Columbia Univesity Press, New York, NY. p.351367.

10.CHAPIN, F. S. I., ZAVALETA, E. S., EVINER, V. T., NAYLOR, R. L., VITOUSEK, P. M., REYNOLDS, H. L., HOOPER, D. U., LAVOREL, S., SALA, O. E., HOBBIE, S. E., MACK M. C. \& DIAZ. S. 2000. Consequences of changing biodiversity. Nature 405:234-242.

11.CHEN, G. \& PETERSON, A.T. 2002. Prioritization of areas in China for biodiversity conservation based on the distribution of endangered bird species. Bird Conservation International 12:197-209.

12.CSUTI, B., POLASKY, S., WILLIAMS, P. H., PRESSEY, R. L., CAMM, J. D., KERSHAW, M., KIESTER, A. R., DOWNS, B., HAMILTON, R., HUSO M. \& SAHR, K. 1997. A comparison of reserve selection algorithms using data on terrestrial vertebrates in Oregon. Biological Conservation 80:83-97.

13.DAVIS, A. J., JENKINSON, L. S., LAWTON, J. H., SHORROCKS, B. \& S. WOOD. 1998. Making mistakes when predicting shifts in species range in response to global warming. Nature 391:783-786.
14.DINERSTEIN, E. \& WIKRAMANAYAKE, E. D. 1993. Beyond "hotspots": How to prioritize investments to conserve biodiversity in the Indo-Pacific region. Conservation Biology 7:53-65.

15.EGBERT, S.L., PETERSON, A. T., SANCHEZ-CORDERO, V. \& PRICE, K. P. 1998. Modeling conservation priorities in Veracruz, Mexico. Pages 141-150 In (S. Morain, ed.). GIS in natural resource management: Balancing the technical-political equation. High Mountain Press, Santa Fe, New Mexico.

16.EITEN, G. 1992. Natural Brazilian vegetation types and their causes. Anais da Academia Brasileira de Ciências 64:35-65.

17.ERASMUS, B. F. N., VAN JAARSVELD, A. S., CHOWN, S. L., KSHATRIYA, M. \& WESSELS, K. J. 2002. Vulnerability of South African animal taxa to climate change. Global Change Biology 8:679-693.

18.FERIA, T. P. \& PETERSON, A.T. 2002. Using point occurrence data and inferential algorithms to predict local communities of birds. Diversity and Distributions 8:4956.

19.GODOWN, M. E. \& PETERSON, A.T. 2000. Preliminary distributional analysis of U.S. endangered bird species. Biodiversity and Conservation 9:1313-1322.

20.GRINNELL, J. 1917. Field tests of theories concerning distributional control. American Naturalist 51:115-128.

21.HOLT, R. D. \& GAINES, M. S. 1992. Analysis of adaptation in heterogeneous landscapes: Implications for the evolution of fundamental niches. Evolutionary Ecology 6:433-447.

22.KLINK, C. A., MOREIRA, A. G. \& SOLBRIG, O. T. 1993. Ecological impacts of agricultural development in the Brazilian Cerrados. In The World's Savannas: Economic Driving Forces, Ecological Constraints and Policy Options for Sustainable Land Use. (M. D. Young,. \& O. T. Solbrig, eds.). Parthenon Publishing, Carnforth, U.K.

23.KOCH, I., SIQUEIRA, M. F. \& PETERSON, A.T. Submitted. Characterizing geographic distributions of tropical woody plant species via ecological niche modeling. Global Ecology and Biogeography.

24.KRONKA, F.J.N., NALON, M.A., MATSUKUMA, C.K., PAVÃO, M., GUILLAUMON, J.R., CAVALLI, A.C., GIANNOTTI, E., IWANE, M.S.S., LIMA, L.M.P.R., MONTES, J., DEL CALI, I.H. \& HAACK, P.G. 1998. Áreas de domínio de Cerrado no Estado de São Paulo. São Paulo. Secretaria de Estado do Meio Ambiente, Instituto Florestal. 84p.

25.LOMOLINO, M. V. 1994. An evaluation of alternative strategies for building networks of nature reserves. Biological Conservation 69:243-249. 
26.MACARTHUR, R. 1972. Geographical Ecology. Princeton University Press, Princeton, N.J.

27.MARTÍNEZ-MEYER, E. 2002. Evolutionary Trends in Ecological Niches of Species. Ph.D. dissertation. University of Kansas, Lawrence, Kansas.

28.MINISTÉRIO DO MEIO AMBIENTE. 1998. Primeiro Relatório Nacional para a Convenção sobre Diversidade Biológica. Ministério do Meio Ambiente, dos Recursos Hidricos e da Amazônia Legal, Brasilia, Brazil.

29.MITTERMEYER, R. A., MYERS, N. and MITTERMEYER, C. G. 1999. Hotspots Earth's biologically richest and most endangered terrestrial ecoregions. New York: CEMEX, Conservation International. 430p.

30.MYERS, N. 1988. Threatened biotas: "Hot spots" in tropical forests. Environmentalist 8:187-208.

31.MYERS, N., MITTERMEIER, R.A., MITTERMEIER, C.G., FONSECA, G.A.B. \& KENT, J. 2000. Biodiversity hotspots for conservation priorities. Nature 403:853-858.

32.NEPSTAD, D. C., KLINK, C. A., UHL, C., VIEIRA, I., LEFEBVRE, P., PEDLOWSKI, M., MATRICARDI, E., NEGREIROS, G., BROWN, I., AMARAL, E., HOMMA, A. \& WALKER, R. 1997. Land-use in Amazonia and the Cerrado of Brazil. Ciencia e Cultura 49:73-86.

33.OLIVEIRA, P. E. \& GIBBS, P. E. 2002. Pollination and Reproductive Biology. In Cerrado Plant Communities. In: The Cerrados of Brazil. Ecology and Natural History of a Neotropical Savana. (Oliveira, P. E. \& R. J. Marquis, R. J. eds). Columbia Univesity Press, New York, NY. p.329347.

34.OLIVEIRA, P. E. \& MARQUIS, R. J. (eds) 2002. The Cerrados of Brazil. Ecology and Natural History of a Neotropical Savana. Columbia University Press, New York, NY. 424p.

35.PETERSON, A. T. 2001. Predicting species' geographic distributions based on ecological niche modeling. Condor 103:599-605.

36.PETERSON, A. T., BALL, L. G. \& COHOON, K. C. $2002 \mathrm{a}$. Predicting distributions of tropical birds. Ibis 144:e27e32.

37.PETERSON, A. T. \& COHOON, K. C. 1999. Sensitivity of distributional prediction algorithms to geographic data completeness. Ecological Modelling 117:159-164.

38.PETERSON, A. T., EGBERT, S. L., SANCHEZ-CORDERO, V. \& PRICE, K. P. 2000. Geographic analysis of conservation priorities using distributional modelling and complementarity: Endemic birds and mammals in Veracruz, Mexico. Biological Conservation 93:85-94.

39.PETERSON, A. T., ORTEGA-HUERTA, M. A., BARTLEY, J., SANCHEZ-CORDERO, V., SOBERON, J., BUDDEMEIER, R. H. \& STOCKWELL, D. R. B. 2002b. Future projections for Mexican faunas under global climate change scenarios. Nature 416:626-629.
40.PETERSON, A. T., PAPES, M. \& KLUZA, D. A. In pressa. Predicting the potential invasive distributions of four alien plant species in North America. Weed Science.

41.PETERSON, A. T., SANCHEZ-CORDERO, V., BEARD, C. B. \& RAMSEY, J. M. 2002c. Ecologic niche modeling and potential reservoirs for Chagas disease, Mexico. Emerging Infectious Diseases 8:662-667.

42.PETERSON, A. T., SÁNCHEZ-CORDERO, V., SOBERÓN, J., BARTLEY, J., BUDDEMEIER, R. H. \& NAVARROSIGÜENZA, A. G. 2001. Effects of global climate change on geographic distributions of Mexican Cracidae. Ecological Modelling 144:21-30.

43.PETERSON, A. T., SCACHETTI-PEREIRA, R. \& KLUZA, D. A. In press-b. Assessment of invasive potential of the glassy-winged sharpshooter Homalodisca coagulata in California and South America. Biota Neotropica. 3(1): http://www.biotaneotropica.org.br/v3n 1/pt/ abstract?article+BN00703012003.

44.PETERSON, A. T., SOBERON, J. \& SANCHEZCORDERO, V. 1999. Conservatism of ecological niches in evolutionary time. Science 285:1265-1267.

45.PETERSON, A. T., STOCKWELL, D. R. B. \& KLUZA, D. A. 2002d. Distributional prediction based on ecological niche modeling of primary occurrence data. Pages 617623 in J. M. Scott, editor. Predicting species occurrences: Issues of scale and accuracy. Island Press, Washington, D.C.

46.PETERSON, A. T. 2003. Projected climate change effects on Rocky Mountain and Great Plains birds: Generalities of biodiversity consequences. Global Change Biology (in press).

47.RATTER, J. A., BRIDGEWATER, S., ATKINSON, R. \& RIBEIRO, J.F. 1996. Analysis of the floristic composition of the Brazilian cerrado vegetation: II. Comparison of the woody vegetation of 98 areas. Edinburgh Journal of Botany 53:153-180.

48.RATTER, J. A., RIBEIRO, J. F \& BRIDGEWATER, S. 1997. The Brazilian Cerrado Vegetation and Threats to its Biodiversity. Annals of Botany 80: 223-230.

49.RATTER, J. A., BRIDGEWATER, S., \& RIBEIRO, J. F., DIAS, T. A. B. \& SILVA, M. R. 2000. Estudo da distribuição das espécies lenhosas da fitofisionomia Cerrado sentido restrito nos estados compreendidos pelo bioma Cerrado. Boletim do Herbário Ezechias Paulo Heringer, Brasilia 5:5-43.

50.RATTER, J.A., BRIDGEWATER, S., RIBEIRO, J. F. 2002. Biodiversity Patterns of Woody Cerrado Vegetation: An Overall View. In Biodiversidade, Conservação e Uso Sustentável da Flora do Brasil. Sociedade Botânica do Brasil. (E. L. Araújo, E. V. S. B. Sampaio, L. M. S. Gestinari,. \& J. M. T. Carneiro. eds.) Universidade Federal Rural de Pernambuco. Recife, PE. Pages 55-57. 
51.SALA, O. E., CHAPIN III, F. S., ARMESTO, J. J., BERLOW, R., BLOOMFIELD, J., DIRZO, R., HUBER-SANWALD, E., HUENNEKE, L. F., JACKSON, R. B., KINZIG, A., LEEMANS, R., LODGE, D., MOONEY, H. A., OESTERHELD, M., POFF, N.L., SYKES, M. T., WALKER, B. H., WALKER, M. \& WALL, D.H. 2000. Global biodiversity scenarios for the year 2100. Science 287:1770-1774

52.STOCKWELL, D. R. B. 1999. Genetic algorithms II. Pages 123-144 in A. H. Fielding, editor. Machine learning methods for ecological applications. Kluwer Academic Publishers, Boston.

53.STOCKWELL, D. R. B. \& NOBLE, I. R. 1992. Induction of sets of rules from animal distribution data: A robust and informative method of analysis. Mathematics and Computers in Simulation 33:385-390.

54.STOCKWELL, D. R. B. \& PETERS, D. P. 1999. The GARP modelling system: Problems and solutions to automated spatial prediction. International Journal of Geographic Information Systems 13:143-158.

55.STOCKWELL, D. R. B. \& PETERSON, A.T. 2002a. Controlling bias in biodiversity data. Pages 537-546 in J. M. SCOTT, editor. Predicting species occurrences: Issues of scale and accuracy. Island Press, Washington, D.C.

56.STOCKWELL, D. R. B. \& PETERSON, A.T. 2002b. Effects of sample size on accuracy of species distribution models. Ecological Modelling 148:1-13.

Title: Consequences of Global Climate Change for Geographic Distributions of Cerrado Tree Species

Authors: Marinez Ferreira de Siqueira \& Andrew Townsend Peterson

Biota Neotropica, Vol. 3 (number 2): 2003

http://www.biotaneotropica.org.br/v $3 \mathrm{n} 2 / \mathrm{pt} /$ abstract?article+BN00803022003

Date Received 01/27/2003 - Revised 04/15/2003

Accepted 07/21/2003

ISSN 1676-0611

http://www.biotaneotropica.org.br 